\title{
PENGEMBANGAN DESAIN DAN PENDEKATAN \\ PERENCANAAN (PLANNING) DALAM MANAJEMEN \\ PENDIDIKAN ISLAM
}

\author{
Abdurrahman \\ Universitas Nurul Jadid \\ rahman.gibol90@gmail.com
}

\begin{abstract}
Abstrak: Perencanaan pendidikan merupakan suatu proses penyusunan alternatif kebijaksanaan guna mengatasi persoalan yang akan dilaksanakan dalam rangka untuk mencapai tujuan pembangunan pendidikan nasional dengan mempertimbangkan kenyataan-kenyataan yang ada di bidang sosial, ekonomi, sosial, budaya, dan kebutuhan pembangunan secara menyeluruh terhadap pendidikan nasional. Perencanaan pendidikan yang bersifat rasional dan sistematik terhadap proses pengembangan pendidikan, bertujuan untuk menjadikan pendidikan menjadi lebih efektif dan efisien dalam menanggapi kebutuhan dan tujuan peserta didik.

Kata Kunci: Desain, Perencanaan, Manajemen Pendidikan
\end{abstract}




\section{Pendahuluan}

Dalam mengelola lembaga pendidikan diperlukan adanya kegiatan perancanaan (planning). Hal ini dikarenakan, perencanaan pendidikan sebagai suatu alat untuk mengatur sistem pendidikan yang penyesuaiannya dengan kebutuhan dan aspirasi seseorang dan masyarakat. Perencanaan harus mampu melihat bagaimana gambaran masyarakat pada masa yang mendatang dan adalah tugas perencanaan untuk menyesuaikan sistem pendidikan ke arah itu. E.C. Bebby dalam tulisannya memberikan definisi tentang perencanaan pendidikan yang dianut banyak negara berkembang termasuk Indonesia. la mengemukakan suatu definisi sebagai berikut:

"Educational planning is the exercising of foresight in determining the policy, priorities and costs of an educational system, having dueregard for economic and political realities, for the systems potential for growth, and for the needs of the country and the pupils served by the system"." "(Perencanaan pendidikan adalah suatu usaha melihat ke masa depan dalam hal menentukan kebijakan, prioritas dan biaya pendidikan dengan mempertimbangkan kenyataankenyataan yang ada dalam bidang ekonomi, sosial, dan politik untuk pengembangan potensi dalam sistem pendidikan nasional, memenuhi kebutuhan bangsa dan peserta didik yang dilayani oleh sistem tersebut)".

Berdasarkan definisi tersebut di atas, memperlihatkan dimensi baru dalam perencanaan pendidikan. Perbedaan yang mencolok dengan tipe perencanaan klasik ialah dalam hal besarnya perhatian yang dibebankan kepada pertumbuhan ekonomi, pengembangan sumber tenaga kerja dan terhadap perencanaan makro. Perencanaan tipe klasik tidak memperhatikan hal-hal tersebut. Perencanaan pendidikan diartikan juga sebagai strategi $i^{2}$ atau cara untuk mencapai tujuan pendidikan agar dapat lebih efektif dan efisien. Perencanaan dalam pengerartian yang lebih luas ialah sebagai penggunaan analisa yang bersifat rasional dan sistematik terhadap proses pengembangan pendidikan yang bertujuan untuk menjadikan pendidikan menjadi lebih efektif dan efisien.

Perencanaan pendidikan di Indonesia merupakan suatu proses penyusunan alternatif kebijaksanaan mengatasi persoalan yang akan dilaksanakan dalam rangka pencapaian tujuan pembangunan pendidikan nasional dengan mempertimbangkan kenyataan-kenyataan yang ada baik di bidang sosial, ekonomi, sosial, kebudayaan dan kebutuhan pembangunan secara menyeluruh terhadap pendidikan nasional. ${ }^{3}$

Telah diketahui bahwa perencanaan pendidikan dalam arti yang seluas-luasnya, adalah penggunaan analisa yang bersifat rasional dan sistematik terhadap proses pengembangan pendidikan yang bertujuan untuk menjadikan pendidikan menjadi lebih efektif dan efisien dalam menanggapi kebutuhan dan tujuan murid-murid dan masyarakat.

Perencanaan pendidikan sebagai suatu strategi yang menghasilkan langkah-langkah untuk menuju titik tujuan dengan arah yang ditetapkan oleh garis-garis kebijaksanaan, yang sebenarnya mencakup tiga unsur pokok yang penting dan berlaku umum untuk semua jenis perencanaan, yaitu 1) keadaan sekarang (data dan informasi sebagai hasil potret atas situasi sekarang), 2) keadaan yang diharapkan yang akan dituju dan di capai (sasaran), dan 3) strategi pencapaian sasaran (langkah-langknah. usaha, taktik atau cara). ${ }^{4}$

Perencanaan pendidikan merupakan strategi atau cara untuk mencapai tajuan pendidikan agar dapat lebih efektif dan efisien. Penetapan prioritas kebutuhan dalam perencanaan pendidikan

\section{${ }^{1}$ E.C. Bebby, The Quality of Education in Developing Countries, Harvard University}

Press, 1966, hlm. 4.

${ }^{2}$ Strategi yang dapat menghasilkan langkah-langkah untuk menuju titik tujuan dengan arah yang ditetapkan oleh garis-garis kebijaksanaan, yang sebenarnya mencakup 3 unsur pokok untuk semua jenis perencanaan yang meliputi; keadaan sekarang, keadaan yang diharapkan yang akan dituju dan dicapai (sasaran) dan, strategi pencapaian sasaran (langkah-langkah, usaha, taktik atau cara). Maka, untuk mencapai tujuan pendidikan, beberapa aspek yang diperhatikan antara lain; adanya koordinasi dalam rangka mempertinggi efisiensi, penetapan skala prioritas, dan konsistensi antara berbagai variabel sosial ekonomi suatu masyarakat.

${ }^{3}$ Enoch, Yusuf, Dasar-Dasar Perencanaan Pendidikan, Jakarta: Bumi Aksara, 1992, hlm. 2-4.

${ }^{4}$ Vembriarto, ST, Pengantar Perencanaan Pendidikan, Yogyakarta, 1988, hlm. 39. 
merupakan salah satu aspek yang harus diperhatikan. ${ }^{5}$ Dengan perencanaan yang mapan, maka dapat diketahui hal-hal apa saja yang harus dilakukan terlebih dahulu, sehingga tidak terjadi kekaburan dan kesimpangsiuran dalam mengambil keputusan dan mengambil tindakan dalam pelaksanaan pendidikan.

Perencanaan pendidikan sebagai suatu alat dalam menentukan dan menetapkan langkahlangkah serta usaha yang akan di ambil dalam mencapai tujuan pendidikan. ${ }^{6}$ Dari langkah yang ditetapkan tersebut akan diperkirakan kebutuhan-kebutuhan pendidikan di masa depan yang perlu dilaksanakan terlebih dahulu atau untuk menentukan skala prioritas dalam memenuhi kebutuhan pendidikan.

\section{Landasan Yang Dipakai Dalam Perencanaan Manajemen Pendidikan Islam}

Dalam mengelola lembaga pendidikan Islam, tidak akan terlepas dari kaidah-kaidah yang menjadikan kerja itu terarah dan mempunyai nilai pertanggungjawaban. Begitu pula dalam perencanaanpendidikan tentunya kaidah-kaidah menjadi mutlak diperlukan. Namun sampai saat ini, setidaknya yang penulis ketahui, belum menyebutkan secara jelas dan terperinci ketentuanketentuan yang menjadi landasan kerja perencanaan pendidikan. Sekalipun demikian, setidaknya ada beberapa landasan perencanaan pendidikan sebagaimana dinyatakan oleh St. Vebriarto, yaitu

1. Perencanaan pendidikan itu harus menggunakan pandangan jangka panjang; dalam hubungan dengan perencanaan pendidikan ini dibedakan tiga jangka perencanaan: rencana jangka pendek (1-2 tahun), rencana jangka menengah (4-5 tahun), dan rencana jangka panjang (10-15 tahun).

2. Perencanaan pendidikan itu harus bersifat komprehensif, artinya meliputi keseluruhan sistem pendidikan dengan berbagai bagiannya, meliputi pendidikan formal maupun non formal.

3. Perencanaan pendidikan itu harus diintegrasikan ke dalam perencanaan pembangunan ekonomi dan sosial yang lebih luas, atau dengan perkataan lain perencanaan pendidikan harus merupakan bagain dari perencanaan masyarakat.

4. Perencanaan pendidikan harus merupakan bagain integral daripada manajemen pendidikan. Perencanaan pendidikan harus berhubungan erat dengan proses pengambilan keputusan dan pelaksanaannya.

5. Perencanaan pendidikan harus memperhatikan perkembangan kuantitatif dan kualitatif pendidikan; perencanaan pendidikan harus menjadikan pendidikan lebih relevan, efisien dan efektif. ${ }^{7}$

Peryataan Vebriarto di atas, memberi pemahaman bahwa dalam perencanaan pendidikan harus mempunyai keutuhan sebagai sebuah perencanaan dari pendidikan. Sehingga perencanaan yang dibuat harus tetap memperhatikan unsur-unsur dalam pendidikan, sifat dari pendidikan yang direncanakan, efesiensi dan efektifitas pendidikan, evaluasi atau kontrol, sekaligus tujuan dimana pendidikan diharapkan dalam masyarakat.

Dengan demikian sebuah perencanaan pendidikan harus menganut kaidah-kaidah sebagai berikut:

1. Kontinyuitas; dimana sebuah perencanaan harus bersifat kontinyu terus menerus dalam batas kurun waktu yang sudah ditentukan.

2. Komprehensif; yaitu bahwa sebuah perencanaan harus melihat secara utuh segala elemen yang menjadi garapan perencanaan, sehingga perencanaan itu benar-benar melingkupi segala aspek garapan.

3. Integrasi; yakni dalam perencanaan harus selalu diintegrasikan pada arah dan tujuan yang menjadi harapan atau cita-cita masyarakat secara keseluruhan baik

90.

${ }^{5}$ Husaini Usman, Manajemen: Teori, Praktik, dan Riset Pendidikan. Jakarta: Bumi Aksara, 2006, hlm.

${ }^{6}$ Sindhunata, Pendidikan Kegelisahan Sepanjang Zaman. Yogyakarta:Kanisius, 2001, hlm. 55.

7 St. Vebriarto, Pengantar Perencanaan Pendidikan (Educational Planning),

Yogyakarta: Yayasan Pendidikan (Paramita), 1982, hlm. 44-45. 
dalam sosial maupun ekonomi. Sehingga perencanaan selalu sinergis dengan pembangunan masyarakat.

4. Integral; dalam kapasitas ini perencanaan harus integral dengan manajemen pendidikan. Dimana suatu bangunan terhadap pendidikan jelas akan terkait dengan siapa yang akan menjadi pelaksana dari perencanaan itu.

5. Evaluasi; yakni dalam perecanaan harus menganut evaluasi tertentu dalam kuantitas maupun kualitas yang ada.

\section{Pendekatan Yang Digunakan Dalam Perencanaan Manajemen Pendidikan Islam}

Perencanaan pendidikan dalam rangka mempersiapkan alternatif pemecahan masalah guna memenuhi kebutuhan pendidikan secara realistis harus berpedoman kepada tujuan-tujuan yang telah ditetapkan secarajelas dan terinci. Berbagai tujuan vang telah ditetapkan akan menentukan pula pola pendekatan perencanaannya. ${ }^{8}$

Pendekatan dalam perencanaan pendidikan secara umum dapat dibedakan menjadi tiga pendekatan, yaitu:

1. Pendekatan permintaan masyarakat (social demand approach)

Pendekatan social demand adalah pendekatan dalam perencanaan pendidikan yang didasarkan atas tuntutan atau kebutuhan sosial akan pendidikan. Pendekatan ini didasarkan pada tujuan untuk memenuhi tuntutan atau permintaan seluruh individu terhdap pendidikan pada tempat dan waktu tertentu dalam situasi perekonomian, sosial, politik, dan kebudayaan yang ada pada saat itu.

Dengan menggunakan pendekatan perencanaan seperti ini, maka perencanaan pendidikan pada umumnya harus memperkirakan kebutuhan pada masa yang akan datang dengan mengadakan analisis terhadap:

a. Pertumbuhan penduduk, penduduk usia sekolah.

b. Prosentase penduduk yang bersekolah.

c. Arus murid dari tingkat yang satu ke tingkat yang lebih tinggi (umpamanya dari SD ke SMP dan ke SMU sampai PT).

d. Pilihan atau keinginan masyarakat dan individu tentang macam-macam pendidikan.

Adapun kelemahan dari pendekatan ini, yaitu:

a. Tidak begitu mengindahkan besarnya sumber-sumber dana yang tersedia dan oesarnya alokasi dana dalam bidang lain pada sektor yang sama.

b. Kurang memperhitungkan perlunya keseimbangan demi sifat macam tenaga kerja yang diperlukan oleh sektor lain.

c. Penerimaan murid dalam jumlah banyak, apalagi kalau tidak diimbangi dengan jumlah tenaga pengajar dan fasilitas belajar, cenderung mengakibatkan menurunnya mutu lulusannya.

d. Mengakibatkan masalah nasional tentang alokasi biaya untuk sektor lain. Mengabaikan pola kebutuhan akan tenaga kerja; dan ada kemungkinan bahwa mutu pendidikan cenderung untuk menurun.

Kritik ini tentu saja beralasan karena data sensus penduduk memperhatikan kecenderungan yang menarik bahwa proporsi jumlah tenaga penganggur lulusan pendidikan yang lebih tinggi ternyata lebih besar dibandingkan dengan proporsi penganggur dari lulusan yang lebih rendah. ${ }^{10}$

2. Pendekatan ketenagakerjaan (man power approach)

Yang dimaksud dengan pendekatan ketenagakerjaan (Man Power Approach) menurut A. W. Guruge adalah, "Gearing on educational effort to the fulfilment of national manpower requirements" bahwa pendekatan ini bertujuan mengarahkan kegiatan-kegiatan pendidikan

${ }^{8}$ Udin Syaefudin Sa'ud dan Abin Syamsuddin Makmun, Perencanaan Pendidikan

Suatu Pendekatan Komprehensif, Bandung: Remaja Rosdakarya. Cet II, 2006, hlm. 236.

${ }^{9}$ Enoch, Yusuf, Dasar-dasar Perencanaan Pendidikan, Jakarta: Bumi Aksara, 1992, hlm. 85-98.

${ }^{10}$ Ace Suryadi dan H.A.R. Tilaar, Analisis Kebijakan Pendidikan: Suatu Pengantar. Bandung: Rosdakary, 1993, hlm. 134. 
kepada usaha untuk memenuhi kebutuhan nasional akan tenaga kerja (Man Power atau Person Power).

Pada tahap permulaan pembangunan dimana diperlukan banyak tenaga kerja dari segala tingkatan dan berbagai jenis keahlian, kebanyakan negara mengharapkan supaya pendidikan mempersiapkan dan menghasilkan tenaga kerja yang terampil untuk pembangunan dalam sektor pertanian, industri, perdagangan dan sebagainya, dan juga untuk calon pemimpin yang cerdas dalam profesinya. Untuk itu maka dicoba membuat perkiraan jumlah dan kualitas tenaga kerja yang terampil untuk pembangunan dalam sektor pertanian, industri, perdaganagan dan sebagainya, dan juga untuk calon pemimpin yang cerdas dalam profesinya.

Karena itu maka dicoba membuat perkiraan jumlah dan kualitas tenaga kerja yang dibutuhkan oleh setiap kegiatan pembangunan nasional. Perencanaan pendidikan dalam hal ini diharapkan dapat memberikan keyakinan penyediaan fasilitas dan pengarahan arus murid benarbenar didasarkan atas perkiraan kebutuhan tenaga kerja.

Kebanyakan ahli-ahli ekonomi memilih pendekatan ketengakerjaan ini, karena mereka berpendirian bahwa pertumbuhan ekonomi tidak hanya bergantung kepada sumber-sumber alam dan fasilitas tetapi juga sumber tenaga kerja yang mengolah, menggunakan serta mengelolanya. Man Power Approach memperhatikan terutama jenis dan tingkat pendidikan yang dapat langsung menghasilkan tenaga kerja. Perencanaan pengembangannya (kualitatif dan kuantitatif) didasarkan kepada perbandingan tenaga kerja menurut klasifikasi yang ada serta jumlah yang diperlukan. Misalnya bila diperlukan 100 insinyur, berapa lulusan SMK yang harus ada; perbandingan antara dokter dengan perawat dan sebagainya.

Masalah yang timbul dalam perencanaan tenaga kerja terutama bagi negara yang sedang bekembang seperti Indonesia ini, antara lain;

a. Jenis dan jumlah tenaga kerja.

b. Persyaratan yang jelas mengenai mutu personil yang dituntut oleh pasaran tenaga kerja.

c. Perbandingan jumlah personil berdasarkan jenjang keahlian.

d. Kebutuhan yang riil akan tenaga kerja. ${ }^{11}$

3. Pendekatan nilai imbalan ( rate of return approach)

Pendekatan ini juga disebut pendekatan cost-benefit yang prinsipnya adalah prinsip yang wajar diketahui oleh setiap orang dalam hal penggunaan uang apabila orang ingin memperoleh hasil yang melebihi pengeluarannya. ${ }^{12}$

Dalam pendekatan ini dipertimbangkan penentuan besarnya investasi dalam dunia pendidikan sesuai dengan hasil, keuntungan atau efektifitas yang akan diperolehnya. Dalam hal ini bukan hanya biaya keseluruhan pendidikan tetapi juga biaya sesuatu jenjang dan jenis pendidikan selalu dibandingkan dengan nilai hasil, misalnya kenaikan pendapatan atau kenaikan produktifitas daripada orang-orang yang sudah memperoleh pendidikan. ${ }^{13}$

\section{Prinsip-Prinsip Yang Digunakan Dalam Perencanaan Manajemen Pendidikan Islam}

Sebagaimana telah dijelaskan terdahulu, bahwa pada dasarnya perencanaan hanyalah alat untuk mencapai tujuan dari pendidikan bukan tujuan itu sendiri. Sehingga efektifitas dari sebuah perencanaan pun tergantung pada aspek-aspek yang lain dari unsur-unsur pendidikan. Bahkan kombinasi yang harmonis dengan alat-alat yang lain akan menjadikan perencanaan pendidikan lebih optimal. Dan menjadi suatu yang prinsip, dimana perencanaan pendidikan menganut pada prinsip-prinsip tertentu guna efektifitas dan efisiensi dari perencanaan itu sendiri, sehingga tujuan yang diembannya dalam sistem pendidikan akan terwujud. Adapun prinsip-prinsip dari perencanaan pendidikan adalah sebagai berikut:

${ }^{11}$ A. W. Guruge dalam Djumberansyah Indar, Perencanaan Pendidikan Strategi dan Implementasinya. Surabaya: Karya Abditama, hlm. 33-35.

12 ST. Vembriarto, Pengantar Perencanaan Pendidikan; Educational Planning. Yogyakarta: Andi Offset, 1988, hlm. 49.

${ }^{13}$ Enoch, Yusuf, Dasar-dasar Perencanaan Pendidikan, Jakarta: Bumi Aksara, 1992, hlm. 49 . 
1. Perencanaan harus bersifat komprehensif; yakni bahwa dalam membuat perencanaan harus memandang pendidikan sebagai suatu keseluruhan. Semua aspek pendidikan harus mendapat perhatian. Dengan demikian, dalam perencanaan pendidikan harus konsisten terhadap tujuan-tujuan yang hendak dicapai, jangka pendek maupun jangka panjang dan mencakup semua jenis kebutuhan individu, masyarakat dan pembangunan nasional.

2. Perencanaan pendidikan harus bersifat integral; yaitu bahwa dalam menyususn rencana pendidikan harus terintegrasi dalam perencanaan yang menyeluruh yang sudah tampak dalam sistem dan prosedur pengelolaan pendidikan. Disamping itu perencanaan pendidikan harus selaras dengan kebutuhan sosial dan adanya harmoni, koordinasi yang mantap antar semua unit dan dinas (yang merencanakan).

3. Perencanaan pendidikan harus memperhaikan aspek-aspek kualitatif dan kuantitatif; artinya dalam membuat perencanaan pendidikan, aspek kuantitatif dan kualitatif harus menjadi acuan. Karena keberhasilan sebuah program tidak terlepas dari aspek tersebut.

4. Perencanaan pendidikan harus merupakan rencana jangka panjang dan kontinyu; sebagaimana sifat dari suatu pendidikan yaitu sebuah proses yang bukan pragmatis semata menjadikan sebuah perencanaan juga harus memahaminya sebagai sebuah proses terus menerus. Hanya sekalipun demikian tetap ada jangka tertentu (pendek atau panjang).

5. Perencanaan pendidikan harus didasari efisiensi; sehingga dalam merencanakan sebuah pendidikan dapat menggunakan seefiesiensi mungkin kebutuhan dana dan biaya yang ada diinfestasikan pada kebutuhan yang paling mendasar.

6. Perencaan pendidikan harus dibantu oleh organisasi administrasi yang efisien dan yang dapat diandalkan; data sebagai input dari perencanaan harus memang benar-benar data yang dapat diandalkan. Karena kebenaran data yang ada akan menjadikan perencanaan itu tepat sasaran.

7. Perencanaan pendidikan harus memperhitungkan semua sumber-sumber yang ada atau yang dapat diandalkan; sehingga perencanaan pendidikan yang dibuat akan menjadi perencanaan yang sesuai dengan kebutuhan. ${ }^{14}$

\section{Pengembangan Desain Dalam Perencanaan Manajemen Pendidikan Islam}

Evolusi perubahan masyarakat menuntut perubahan pula dalam perencanaan pendidikan, agar perencanaan mampu menunjang evolusi itu dan dapat mengatasinya. Soumelis menunjukkan faktor-faktor yang mempengaruhi perencanaan pendidikan berevolusi. Faktorfaktor tersebut, di antaranya yaitu:

1. Perubahan tujuan eksteternal dan internal sistem pendidikan.

2. Perubahan berfikir sosial-politik.

3. Semakin berkembangnya sutruktur administrasi pendidikan, setiap lembaga mempunyai struktur sendiri sehingga membutuhkan perencanaan tersendiri.

4. Interes-interes khusus pada para penanggungjawab perencanaan sesuai dengan bidang studi mereka masing-masing.

5. Struktur pendek pada perencanaan yang bersifat mesin artinya suatu perencanaan itu terpusat dikerjakan oleh pemerintah pusat.

6. Tekanan dari problem-problem yang bersifat akut, yang dulu diselesaikan dengan perencanaan jangka pendek yang nantinya seharusnya dikaitkan dengan perencanaan jangka panjang.

Selanjutnya Soumelis juga memberikan informasi-informasi yang sepatutnya dipakai sebagai dasar dalam perencanaan, di antaranya yaitu;

1. Nilai-nilai masyarakat yang dikembangkan lewat pendidikan artinya pendidikan dan perencanaan tidak meninggalkan nilai-nilai masyarakat.

2. Sikap siswa terhadap pendidikan dan pekerjaan.

3. Hasil penelitian untuk pengembangan kurikulum dan pengembangan keputusan.

${ }^{14}$ Djumberansjah, I.M. Perencanaan Pendidikan: Strategi dan Implementasinya, Surabaya : Karya Abditama, 1995, hlm. 12-14. 
4. Fungsi dan performan sistem pendidikan artinya pendidikan kejuruan tidak sama dengan fungsi dan performannya dengan sistem pendidikan umum.

5. Fungsi dan pengembangan pasaran tenaga kerja pada masa mendatang.

6. Kemungkinan efek proses mikro pada teknologi pendidikan. Proses mikro ialah proses yang terjadi pada suatu lembaga pendidikan yaitu proses mengemangkan dan menumbuhkan para siswa melalui kegiatan belajar mengajar.

7. Kemungkinan adanya perkembangan ekonomi. ${ }^{15}$

\section{Konsep Desain Perencanaan}

Desain meliputi tiga esensi dasar yaitu material, bentuk dan relasi dinamis di antara komponen-komponen semuanya. Material adalah dasar pembangunan komplek yang berasal dari fisik sebuah lingkungan yang merupakan dasar medium bagi kerja desainer. Bentuk menghadirkan perpaduan material, bentuk fisik material ke dalam ketepatan batas untuk pembangunan sistem aktifitas. Aspek terakhir dari masalah desainer adalah perpaduan dinamis berbagai gerakan ke dalam perpaduan bebagai sistem. Seperti sebuah konsep desain yang menekankan penerapan keindahan pada proses desain. Seperti, pengaruh pemahatan pada patung atau pengarauh pengecatan pada aspek komposisinya. Hal tersebut jelas bahwa ide kreatifitas diikutkan dalam desain sebuah pemikiran yang mengandung petunjuk seorang desainer yang sangat unik. Sebuah desian dibuat oleh teknisi yang kreatif yang mengkombinasikan kemampuan teknik untuk mengekspresikan ide dengan kreatifitas dan imajinasi yang memasang dan menyusun berbagai hal.

Grillo telah membuat konsep triangular sebuah desain. Berbagai poin komponen proses desain adalah dua kebutuhan pokok, yaitu 1) prosedur tepat (efektif) terhadap lokalisasi dan aktifitas manusia (dengan atau tidak hubungan satu sama lain atau perbedaan penggunaan areal/tanah), 2) kekuatan pemahaman areal/tanah, sebelum mendesain fisik lingkungan. ${ }^{16}$

Tabel Triangular:

Understand The Law Of Nature

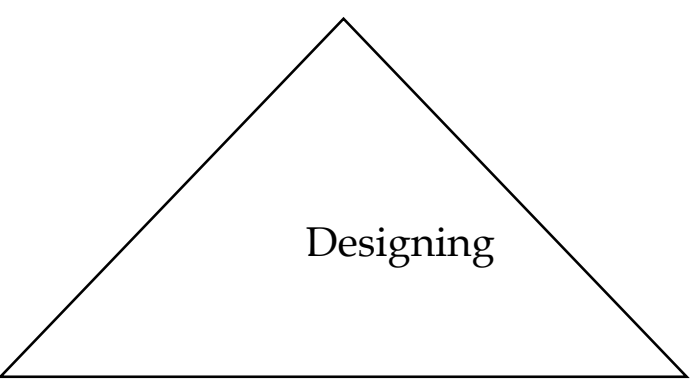

My Own Ideas and Imagination
Undersrand The Character of People and Their Needs

Penekanan pada pergerakan dalam proses desain menonjolkan fakta bahwa desain itu sendiri harus dibentuk untuk memperkenankan katepatan aktifitas pada fungsi dalam fisik lingkungan. Tindakan kreatifitas desain adalah produk akhir yang merefleksikan berbagai personalitas desainer. Keindahan atribut pengalaman desainer, kebijaksanaan konfensional dan terkaan intuisi, semua punya peraturan dalam proses desain.

Desainer harus pandangan luas, kematangan filosofis sosial dan keahlian teknik terhadap analisis yang wajib untuk menyusun rencana yang tepat. Desain dapat secara utuh menerapkan kedisiplinan analisis sistem. Kemampuan teknik dan orientasi umum yang menyediakan

${ }^{15}$ Soumelis dalam Made Pidarta. Perencanaan Pendidikan Partisipatori dengan Pendekatan Sistem. Jakarta: Rineka Cipta. 1990, hlm: 10-13.

${ }^{16}$ F.W. Banghart \& Trull. Jr. A. Educational Planning. New York: The Macmillan Company. 1973, hlm: 276. 
pendekatan pada keseluruhan desain. ${ }^{17}$ Kebanyakan penekanan dalam desain ditempatkan pada optimalisasi fungsi relasi. Perencanaan desain sebagai akibat adanya hubungan antara fasilitas dan perpaduan yang erat antara waktu dan jarak.

\section{Pengaruh-Pengaruh Dalam Perencanaan Desain}

Masalah desain adalah masalah yang kompleks dan dipengaruhi oleh berbagai faktor termasuk seperti kultur, politik, alam dan lingkungan. Faktor lain yang mempengaruhi perencanaan adalah iklim, psikologi, teknologi dan perubahan sosial kultur. Perubahan kultur menjadi sangat penting dan mempengaruhi teknologi dalam membuat struktur lingkungan.

Faktor lain yang mempengaruhi proses desain meliputi kegunaan waktu, perencanaan yang komprehensif, interaksi sosial, perkembangan ekonomi dan edukasi yang mempengaruhi pendekatan tersebut, seperti pendekatan asumsi kegunaan seluruh teknologi modern untuk analisis dan perencanaan. Hanya ketika fenomena itu disadari sekaligus dipelajari dalam bentuk interaksi perencanaan pendidikan yang komprehensif akan berjalan secara optimal. ${ }^{18}$ Desain yang sukses harus mengkomposisikan seluruh elemen yang tersedia di alam tanpa memberikan penekanan elemen tersebut.

\section{Proses Desain}

Proses desain bermula dengan peninjauan lingkungan dan persiapan reseach berdasarkan data yang akurat tentang solusi desain yang diambil, dan beberapa tipe dokumentasi grafik yang diubah. Tahap operasi yang utama bermula pendefinisian masalah desain yang biasanya difasekan dalam bentuk kebutuhan abstrak. Desain proses termasuk bidang yang luas dengan permulaan aktifitas dari sebuah survei, spesifikasi obyektif, solusi alternatif penerimaan data dalam artikulasi dan integrasi yang krusial. ${ }^{19}$

Desain proses dalam perencanaan berkembang melalui definisi orisinal, pengumpulan data, modifikasi bentuk, solusi memperoleh modifikasi sehingga dari proses ini perancang mencoba menafsirkan kebutuhan sosial masyarakat serta memenuhinya sesuai dengan bentuk fisik yang ada. Bagaimanapun perancang deiperlukan pengembangan berbagai metodologi yang akan mengekspresikan keinginan dan kebutuhan dasar kliennya (masyarakat).

Sedangkan Morphet memberikan gambaran tentang prosedur-prosedur yang harus diperhatikan dalam membuat perencanaan, yaitu 1) pengumpulan informasi dan analisis data, 2) menyelesaikan perubahan dalam bentuk kebutuhan, 3) mengidentifikasi tujuan dan prioritas, 4) membentuk alternatif-alternatif penyelesaian, dan 5) mengimplementasi, menilai dan memodifikasi. ${ }^{20}$

Dengan demikian langkah-langkah perencanaan atau proses perencanaan adalah melalui tahap-tahap sebagai berikut:

1. Menentukan kebutuhan atas dasar antisipasi terhadap perubahan lingkungan atau masalah yang muncul. Bila kebutuhan banyak diadakan prioritas.

2. Melakukan forecasting/ramalan, menentukan program, tujuan dan misi perencanaan. Bila tujuan banyak diadakan prioritas.

3. Menspesifikasi tujuan.

4. Membentuk/menentukan standar performan.

5. Menentukan alat/metode/alternatif pemecahan.

6. Melakukan implementasi dan menilai.

7. Mengadakan reviuw. ${ }^{21}$

${ }^{17}$ Sindhunata, Menggegas Paradigma Baru Pendidikan: Demokrasi, Otonomi, Civil Society, Globalisasi. Yogyakarta: Kanisius, 2000, hlm. 72.

${ }^{18}$ Ibid, hlm. 278-279.

${ }^{19} \mathrm{Ibid}, \mathrm{hlm} .283$.

${ }^{20}$ Made Pidarta. Perencanaan Pendidikan Partisipatori dengan Pendekatan Sistem.

Jakarta: Rineka Cipta. 1990, hlm. 98.

${ }^{21}$ Ibid, hlm. 99. 
Dari ketujuh langkah itu, langkah pertama dan kedua termasuk dalam kategori perencanaan strategis, sedangkan langkah ketiga sampai dengan langkah ketujuh termasuk perencanaan operasional.

\section{Kesimpulan}

Perencanaan sebagai suatu alat dalam menentukan dan menetapkan langkah-langkah serta usaha yang akan diambil dalam mencapai tujuan pendidikan. Dari langkah-langkah yang telah ditetapkan tersebut diharapkan dapat diperkirakan kebutuhan-kebutuhan pendidikan di masa depan yang perlu dilaksanakan terlebih dahulu (skala prioritas) dari kebutuhan pendidikan.

Di samping itu, perencanaan pendidikan sebagai suatu alat untuk mengatur sistem pendidikan yang penyesuaiannya dengan kebutuhan dan aspirasi seseorang dan masyarakat. Perencanaan harus mampu melihat bagaimana gambaran masyarakat pada masa yang akan datang dan adalah tugas perencanaan untuk menyesuaiakan sistem pendidikan.

Dari pengalaman-pengalaman pelaksanaan perencanaan pendidikan, maka dapatlah ditarik pelajaran, antara lain:

1. Suatu sistem pendidikan hanya dapat direncanakan dengan baik dan dapat diimplementasikan dengan baik apabila pelaksana dan pengelola pendidikan mempunyai tanggung jawab yang baik dan adanya saling jalin-menjalin dan tercapainya tujuan daripada keseluruhan sistem itu.

2. Perencanaan akan terlaksana dengan sebaik-baiknya apabila; a) para pemimpin politik dan pendidikan sungguh-sungguh yakin akan pentingnya perencanaan itu, memberikan dukungan dan secara serius menggunakan perencanaan itu dalam keputusan-keputusan, dan b) orang-orang lain yang secara serius terlibat dalam sistem pendidikan itu, seperti para petugas administrasi, guru, murid, orang tua murid, diberi kesempatan yang wajar untuk memberikan andilnya dalam perumusan rencana-rencana pendidikan.

3. Dalam menghadapi lingkungan/masyarakat yang berubah, ada beberapa tindakan yang mungkin diambil oleh manajer pendidikan, yaitu tindakan untuk bertahan, terus mengadakan perbaikan, melakukan inovasi atau mengadakan perombakan total. 


\section{DAFTAR PUSTAKA}

1988. Pengantar Perencanaan Pendidikan, Yogyakarta.

Yogyakarta: Andi.

2000. Pengantar Perencanaan Pendidikan; Educational Planning.

Banghart F.W. \& Trull. Jr. A. 1973. Educational Planning. New York: The Macmillan Company.

Djumberansyah Indar, 1995. Perencanaan Pendidikan Strategi dan Implementasinya. Surabaya: Karya Abditama.

Enoch, Yusuf. 1992. Dasar-dasar Perencanaan Pendidikan, Jakarta: Bumi Aksara.

Made Pidarta. 1990. Perencanaan Pendidikan Partisipatori dengan Pendekatan Sistem. Jakarta: Rineka Cipta.

Sa'ud, Udin Syaefudin dan Abin Syamsuddin Makmun, 2006. Perencanaan Pendidikan Suatu Pendekatan Komprehensif . Bandung: Remaja Rosdakarya. Cet II.

Sindhunata (ed), 2001. Pendidikan Kegelisahan Sepanjang Zaman. Yogyakarta: Kanisius.

Sindhunata (ed). 2000. Menggegas Paradigma Baru Pendidikan: Demokrasi, Otonomi, Civil Society, Globalisasi. Yogyakarta: Kanisius.

Suryadi, Ace dan H.A.R. Tilaar. 1993. Analisis Kebijakan Pendidikan: Suatu Pengantar. Bandung: Rosdakarya.

Usman, Husaini. 2006. Manajemen: Teori, Praktik, dan Riset Pendidikan. Jakarta: Bumi Aksara.

Vebriarto, St, 1982. Pengantar Perencanaan Pendidikan (Educational Planning), Yogyakarta: Yayasan Pendidikan (Paramita).

Bebby, E.C, 1966, The Quality of Education in Developing Countries, Harvard University Press. 